\title{
The functional properties of fats and oils - A richness of diversity
}

\author{
By Peter Belton \\ Institute of Food Research, Norwich Research Park, Colney, Norwich NR4 7UA, UK \\ e-mail: Peter. Belton @ bbsrc.ac.uk \\ Tel +44 1603255226 \\ Fax +441603458939
}

\section{RESUMEN \\ Las propiedades funcionales de los aceites y grasas. Una gran diversidad}

La importancia de los aceites y grasas se deriva de la funcionalidad que los mismos pueden conferir, debido a sus características químicas y estructurales. Una propiedad clave de los lípidos es su relativa insolubilidad en agua, gracias a su larga región no polar. Sin embargo, los lípidos también contienen grupos con una cierta polaridad. La combinación de estas características de compuestos simultáneamente polares y no polares, así como los diferentes grados de las mismas que pueden encontrarse, son las que les confieren el amplio rango de propiedades funcionales que poseen y su extraordinario valor. En este volumen de Grasas y Aceites se revisan algunas de estas propiedades funcionales. Los Editores esperan que esta edición especial de la Revista constituya una referencia obligada en relación con el estado actual de los conocimientos y las aplicaciones de los temas que se han incluido.

PALABRAS-CLAVE: Aceites - Compuestos anfifílicos Grasas - Propiedades funcionales.

\section{SUMMARY}

The functional properties of fats and oils - A richness of diversity

A part of the importance of fats and oils derives from the functional properties that they confer to the foods. This is a consequence of their chemical nature and structural features. Lipids are relatively insoluble in water because their large non-polar region. However, they also contain groups with some degree of polarity. The combination of these polar and non-polar groups and their variations is what gives the range of functional properties observed and what made them so valuable. This issue of Grasas y Aceites reviews some of the functional properties of fats and oils. The Editors hope that the studies included will provide an state of the art reference volume of present knowledge and applications in these areas.

KEY-WORDS: Amphiphilic compounds - Fats - Functional properties - Oils.

\section{FATS AND OILS-A MAJOR INDUSTRY}

The importance of fats and oils originates in the functionality that they can confer, this in turn arises from their chemical nature and the common structural features that exist in all fats and oils. In the context of this review, the term fats and oils specifically excludes mineral products and applies to what are normally called lipids. Lipids are defined by The Condensed Chemical Dictionary (1) as: " An inclusive term for fats and fat derived materials. Includes all substances which: 1. are relatively insoluble in water but soluble in organic solvents..., 2. related either actually or potentially to fatty acid esters, fatty alcohols, sterols, waxes etc..., and 3. utilisable by the animal organism.»

Fats and oils cover a huge range of materials produced in vast tonnage every year. Table I gives world production figures for some major fats and oils. A more up to date analysis for the USA is given in Table II. The scale of consumption is huge and attests to the enormous importance of fats and oils to the global economy as well as the role that they play in our every day lives.

\section{Table I}

World production of fats and oils in thousands of metric tonnes

(source Ref. 2)

\begin{tabular}{lccc}
\hline OIL OR FAT & $1985 / 86$ & $1987 / 88$ & $1989 / 90$ \\
\hline Soya & 14240 & 15530 & 16120 \\
Cottonseed & 3700 & 3593 & 3588 \\
Groundnut & 3324 & 3489 & 3787 \\
Sunflower & 6894 & 7557 & 7767 \\
Rape & 6246 & 7842 & 8025 \\
Olive & 1870 & 2198 & 1736 \\
Coconut & 3334 & 2937 & 3187 \\
Palm & 7294 & 8575 & 10920 \\
Palm Kernel & 992 & 1152 & 1421 \\
Other Vegetable & 2754 & 2965 & 2995 \\
Butterfat & 6493 & 5387 & 5344 \\
Lard & 5092 & 5386 & 5344 \\
Tallow & 6488 & 6773 & 6559 \\
\hline
\end{tabular}


Table II

Oil and fat production in the United States for 1997 in thousands of metric tonnes (source Ref. 3)

\begin{tabular}{lc}
\hline OIL OR FAT & Production \\
\hline Cottonseed & 551 \\
Soya & 7339 \\
Corn & 1014 \\
Groundnut & 76 \\
Lard & 171 \\
Tallow (edible) & 670 \\
Coconut (refined) & 162 \\
Sunflower & 29 \\
Vegetable Oil Foods & 129 \\
Tall Oil & 672 \\
Tallow (inedible and grease) & 2812 \\
Tung & 9 \\
Fish & 13 \\
Safflower & 9 \\
Rapeseed (refined) & 118 \\
\hline
\end{tabular}

Table III gives a further analysis of the data from the US for edible and inedible fats and oils. The total consumption of edible products is two and a half times that of inedible products attesting to the role of the food industry as consumers of fats and oils and their overall importance in food products.

Table III

Consumption of fats and oils in edible and inedible products for 1997. Figures are in thousands of metric tons (source Ref. 3)

\begin{tabular}{lc}
\hline EDIBLE PRODUCTS & CONSUMPTION \\
\hline Baking and Frying Fats & 2555 \\
Salad or Cooking Oil & 3358 \\
Margarine & 780 \\
Other Products & 134 \\
TOTAL & 6827 \\
\hline
\end{tabular}

\begin{tabular}{lc}
\hline INEDIBLE PRODUCTS & CONSUMPTION \\
\hline Soap & 255 \\
Paint and Varnish & 42 \\
Feed & 1190 \\
Resins and Plastics & 93 \\
Lubricants & 56 \\
Fatty Acids & 1053 \\
Other Products & 251 \\
TOTAL & 2941 \\
\hline
\end{tabular}

\section{FUNCTIONALITY}

The origins of the functionality of fats and oils lies in the chemical constitution. As the definition given above implies a key feature of lipids is their relative insolubility in water, this arises because all lipid molecules have a common feature of containing a large non-polar region. This is highly variable and may itself contain a wide range of chemical species. However the second common feature of lipids is that they all contain a functional group or groups which have some degree of polarity. It is the combination of the polar and non-polar and the variations that are possible within these that give the range of functional properties that are observed and are of such value.

In order to try to classify this diversity it is useful to define a general formula for a lipid. A suitable one might be:

$$
R_{(n)}-P_{(m)}
$$

In this representation $\mathrm{R}$ represents the hydrophobic entity and $P$ the more polar entity. There are in general $\mathrm{n}$ hydrophobic species attached $\mathrm{m}$ polar species. Where $\mathrm{n}$ is greater than 1 . It is not a necessary requirement that $R_{1}=R_{2}=R_{3}$, a similar consideration applies for $\mathrm{P}$ and $\mathrm{m}$. There is no implication of stereochemistry in this formula and this is, of course, another source of the diversity of lipid functionality.

In the simplest case of a fatty acid $n=1$ and $m=1$, even here there is enormous variation possible in $R$. In the important case of a tryglyceride $P$ remains fixed but the number of possible combinations of $R$ is very great. Variations in $R_{1}, R_{2}$ and $R_{3}$ result in variations in melting temperatures of solids and in the general case where $R$ contains sufficient carbon atoms to give alkyl chain flexibility a number of crystal habits are possible. Examples of the effects of changes in $\mathrm{R}$ on melting point and crystal habit are given in Table IV. 
Table IV

Melting points of various crystal habits of triglycerides. Melting points are given in degrees Celsius. Data from Ref. 4

\begin{tabular}{lcccc}
\hline TRIACYLGLYCEROL & $\alpha$ & $\beta_{1}^{\prime}$ & $\beta_{2}{ }_{2}$ & $\beta$ \\
\hline Tricaprin & -15.0 & & & 31.5 \\
Trilaurin & 15.0 & & & 46.5 \\
Trimyristin & 33.0 & 54.5 & & 57.0 \\
Tripalmitin & 45.0 & 63.5 & & 65.5 \\
Tristearin & 54.5 & 70.0 & & 72.0 \\
2-Lauroyldidecanoin & 6.0 & 37.5 & 34.0 & \\
2-Myristyldilaurin & 24.0 & 48.0 & 44.0 & \\
2-Palmitoyldimyristin & 38.0 & 58.5 & 55.0 & \\
2-Stearoyldipalmitin & 49.0 & 68.0 & 65.0 & \\
Triolein & -32.0 & -12.0 & 49.0 & \\
Trielaidin & 15.5 & 37.0 & 42.0 & \\
Trierucin & 6.0 & 17.0 & 30.0 & \\
\hline
\end{tabular}

In most commercially available fats and oils there is a range of $R_{n}$. Examples of these are shown in chart 1 and illustrate the diversity of properties that will be available from different fats and oils. It is important to realise that the useful functionalities such as mouth feel derive not the presence of a single compound but from the variety of chemical and physical properties present. These will control such features as the solid liquid ratio at room temperature and the subsequent changes on exposure to body temperature in the mouth. Thus in this and many other cases, such a spreadability, important functionality comes from the mixture of materials present.

When $\mathrm{R}$ contains some chemical functionality that confers stiffness on the chain stereochemical effects start to become important. These can effect

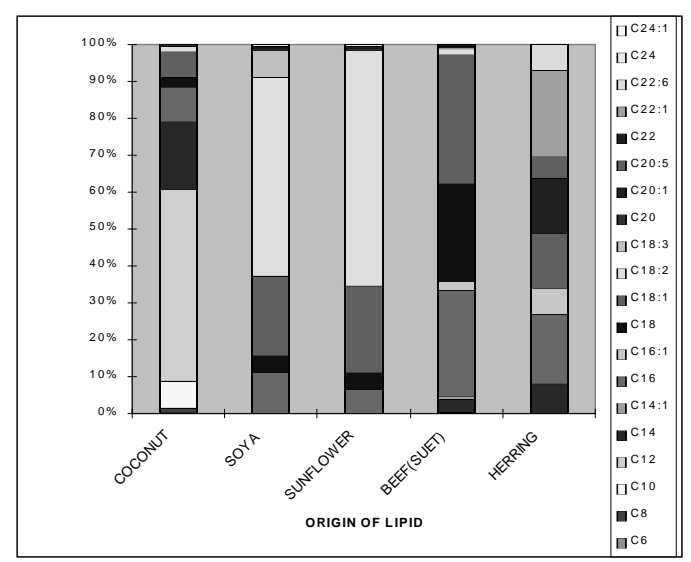

Chart 1

The variation in fatty acid content of lipids from various sources the packing of the chains and also will effect the chemical reactivity of the lipid. An example of this can be seen in the unsaturated chains. Cis -trans isomerism is very important in determining the nutritional value of lipids and the presence of double bonds in the alkyl chain restricts the ability to fit into membrane structures and increases fluidity. The interactions of macromolecules with the lipid may also be affected by the nature of $R$. The degree of stiffness of $R$ and the nature of the chemical entity causing the stiffness will determine the restrictions on the interactions and in the some circumstances can give rise to highly stereospecific recognition.

The nature of the polar group is of vital importance in the interaction of the lipid with water: highly polar or charged groups will tend to be hydrophilic in nature and thus will tend to orient towards water whilst the hydrophobic groups will tend to orient towards non polar regions. These competing effects give rise to the surface activity that is often observed in lipids and to the formation of complex structures such as micelles and bilayers such as occur in membranes. Further complex liquid crystalline structures may also be formed giving rise to yet another range of diversity.

\section{THE LITERATURE}

It is not surprising that given the importance of fats and oils that there is a vast literature covering both the academic and commercial aspects of the subject.

The range of periodicals alone is enormous. Table $\mathrm{V}$ gives a partial list of some the periodicals dealing with lipid and lipid related research.

It is clear from the list that lipids and their wide variety of functions impinge on almost all aspects of human life and that importance of lipids at the national level is reflected by the number of national periodicals covering particular aspects of lipid science and technology.

\section{CONCLUSIONS}

Fats and oils are commercially and scientifically of great importance. In the following volume of Grasas y Aceites we review some of the functional properties of fats and oils. As must be clear from the foregoing any such review must be incomplete and partial. Nevertheless the editorial group hopes that this special edition of the Journal will provide a useful and up to date reference volume of current thinking and applications in the areas selected.

\section{ACKNOWLEDGEMENT}

The Author would like to thank Rebecca Sweet for help in the preparation of Table V. 
Table V

A list of periodicals dealing with lipid research

Advances in Applied Lipid Research

Advances in Lipid Methodology

Agribusiness Dairyman

American Oil Chemists' Society. Journal

Aromes, Ingredients, Additifs

Australia. Bureau of Statistics. Dairying and Dairy Products,

Australian Bureau of Agricultural and Resource Economics. Australian

Australian Dairy Foods; Production - Processing - Packaging - Marketing

Australian Bureau of Agricultural and Resource Economics. Australian Commodity

Statistics (Year)

Australian Dairy Farmer

Australian Dairy Foods

Australian Journal of Dairy Technology

Ayrshire Dairyman

B C Dairy Directory

Biochimica et Biophysica Acta - Molecular and Cell Biology of Lipids

Bulletin of the International Dairy Federation

Business Ratio Plus: Dairy Industry

C A Selects. Fats \& Oils

C A Selects. Omega-3 Fatty Acids \& Fish Oil

California Dairy Information Bulletin

California. Agricultural Statistics Service. Dairy Industry Statistics

Canada. Statistics Canada. Dairy Review

Canada. Statistics Canada. Food Industries

Canada. Statistics Canada. Oils and Fats

Cereals and Oilseeds Review

Cheese Market News

Chemistry and Physics of Lipids

China Feed, Grain and Oilseed

China Oils and Fats

Congress of the International Society for the Study of Fatty Acids and Lipids

Cream Separator and Dairy Newsletter

Current Industrial Reports: Fats and Oils. Oilseed Crushings

Current Opinion in Lipidology

D A I S Y - The Dairy Information System

D M Z - Lebensmittelindustrie und Milchwirtschaft; magazine for food and dairy industry

Dairy - Deli - Bake Digest

Dairy and Field Crop Digest

Dairy Council Digest; an interpretive review of recent nutrition

Dairy Executive

Dairy Facts and Figures

Dairy Farmer

Dairy Field; the how-to magazine for dairy processor growth

Dairy Foods Industry Guide

Dairy Foods Market Directory

Dairy Foods Newsletter

Dairy Foods; innovative ideas and technologies for dairy processors
Indian Journal of Dairy Science

International Association of Food Industry Suppliers. Reporter

International Dairy Federation. Bulletin

International Dairy Federation. Catalogue of I D F Publications

International Dairy Federation. International Standard

International Dairy Journal

International Food Abstracts. Dairy Disk

International Food Ingredients

International Journal of Dairy Technology

Ireland. Department of Agriculture and Food. Root Fodder Crop, Pulse and Oilseed Varieties Recommended List (Year)

Jacobsen's Fats \& Oils Bulletin

Journal of Dairy Research

Journal of Dairy Science

Journal of Dairying, Foods \& Home Sciences

Journal of Essential Oil Research

Journal of Food Lipids

Journal of Lipid Mediators and Cell Signalling

Journal of Lipid Research

Journal of Oil Palm Research

Journal of the American Oil Chemists Society

Journal of the Japanese Oil Chemists Society

Kansanka Shishitsu Kenkyu Parallel Title: Lipid Peroxide and Research

Kautschuk Gummi Kunststoffe

Key Note Market Report: Milk \& Dairy Products

Korean Journal of Dairy Science

Legume, root, oilseed and fibre crops

Lipid

Lipid File

Lipid Protein Interactions

Lipid Review

Lipid Technology

Lipid Technology Newsletter

Lipids

Market Leaders in the World Dairy Industry

National Dairy Council. Quarterly Review

National Dairy Research Institute. Annual Report

National Oilseed Processors Association. Yearbook and Trading Rules

Netherlands. Centraal Bureau voor de Statistiek. Productie Statistiek van de Zuivelindustrie Parallel Title: Netherlands. Central Bureau of Statistics. Production Statistics of the Dairy Industry

New York State Dairy Statistics

New Zealand Dairy Board. Annual Report and Statement of Accounts

New Zealand Dairy Exporter

Nigerian Journal of Palms and Oil Seeds

Nordic Lipid Symposium

Nyugikyo Shiryo Parallel Title: Japan Dairy Technical Association. Bulletin

$O C$ L; (Oleagineux Corps gras Lipides)

Oil World Weekly; the weekly forecasting and information service for oilseeds, oilmeals, oils and fats 
Dairy Goat Journal

Dairy Goat Society of Australia. Victorian Branch Newsletter

Dairy Guide

Dairy India Yearbook

Dairy Industries International

Dairy Industry Bulletin

Dairy Industry Leader

Dairy Mail

Dairy Market News

Dairy Market Statistics: Annual Summary

Dairy Markets Weekly

Dairy Monthly Imports

Dairy Moves

Dairy News

Dairy Policy

Dairy Producer

Dairy Products

Dairy Products: A World Survey

Dairy Products: The International Market

Dairy R \& D News

Dairy Roundup

Dairy Science Abstracts

Dairy Today

Dairy World

Dairy, Food and Environmental Sanitation

Dairy: Latin American Industrial Report

Dairyfarming Annual

Dairymen's Digest

Dairymen's League News

Department of Statistics. Cocoa, Coconut and Tea Statistics Handbook, Malaysia

Drugs affecting lipid metabolism

Egyptian Journal of Dairy Science

European Dairy Magazine

European Journal of Lipid Science

Field Crop Abstracts; monthly abstract journal on world annual cereal,

Finnish Journal of Dairy Science

Food Ingredients \& Analysis International

Grain and Oilseeds

Grains Research and Development Corporation. Annual Report

Grasas y Aceites

Handbook of Lipid Research

Hoard's Dairyman; the national dairy farm magazine

Hormone Research

I D D A Wrap-Up

I N F O R M: International News on Fats, Oils \& Related Materials

Indian Dairyman
Oils \& Fats International

Oils and Fats International Directory

Oils and Fats: The International Market

Oils and Oilseeds Journal (also daily bulletin)

Oilseeds and Industrial Crops

Oilseeds, oilmeals, oils and fats

Oily Press - book series

Omega 3 and 6 News Online

Ontario Dairy Farmer Magazine

Ontario. Ministry of Agriculture, Food and Rural Analysis. Monthly Dairy

Palm Oil Developments

Palm Oil Technical Bulletin

PORIM Technology

Progress in Lipid Research

Progress in Protein - Lipid Interactions

Prostaglandins and Other Lipid Mediators

Prostaglandins, Leukotrienes and Essential Fatty Acids

Queensland Dairyfarmer

Rakuno Gakuen Daigaku Kiyo. Shizen Kagaku Hen Parallel Title: Rakuno Gakuen University. Journal: Natural Science

Retinoids and Lipid-Soluble Vitamins in Clinical Practice

S D I - Scandinavian Dairy Information

$S$ W Dairy Farmer

Seifen Oele Fette Wachse

Shishitsu Seikagaku Kenkyu Parallel Title: Japanese Conference on the Biochemistry of Lipids

South Africa. Milk Board. Annual Report

Soya \& Oilseed Bluebook

Sugar, Food Product, Vegetable Oils, Wheat Product, Fats, Soaps

Teagasc Research Report

Telhan Patrika Parallel Titte: Oilseeds Journal

The Complete Fat Unit Guide

The Market for Dairy Products in South East Asia

The Western Dairyman

Tochigi Prefectural Dairy Experimental Institute. Bulletin

Tropical Agriculture

Weekly Insiders Dairy \& Egg Letter

World Congress of the International Society for Fat Research (ISF).

World Market for Dairy Products

World of Ingredients

Yukagaku Parallel Title: Journal of the Japan Oil Chemists' Society

Zhongguo Rupin Gongye Parallel Title: China Dairy Industry

Z M P Bilanz Dairy Review

\section{REFERENCES}

1. The Condensed Chemical Dictionary, 9th Edition, Van Nostrand Reinhold, New York, 1977

2. M Gordon in «Food Industries Manual», 23rd Edition, MD Ranken and RC Kill (Eds), Blackie, London,1993, p 280
3. US Census Bureau «Fats and Oils; production, Consumption and Stocks» M311K(98)-13, 1998

4. K Larsson and PJ Quinn in «The Lipid Handbook», FD Gunstone, JE Harwood and FB Padley (Eds), Chapman and Hall, London 1994, p 452. 